This item was submitted to Loughborough's Research Repository by the author.

Items in Figshare are protected by copyright, with all rights reserved, unless otherwise indicated.

\title{
A thirst for the authentic: craft drinks producers and the narration of authenticity
}

PLEASE CITE THE PUBLISHED VERSION

https://doi.org/10.1111/1468-4446.12634

\section{PUBLISHER}

John Wiley \& Sons Ltd @ London School of Economics and Political Science

\section{VERSION}

AM (Accepted Manuscript)

\section{PUBLISHER STATEMENT}

This is the peer reviewed version of the following article: THURNELL-READ, T.P., 2019. A thirst for the authentic: craft drinks producers and the narration of authenticity. The British Journal of Sociology, 70 (4), pp.1448-1468, which has been published in final form at https://doi.org/10.1111/1468-4446.12634. This article may be used for non-commercial purposes in accordance with Wiley Terms and Conditions for Use of SelfArchived Versions.

\section{LICENCE}

CC BY-NC-ND 4.0

\section{REPOSITORY RECORD}

Thurnell-Read, Thomas. 2019. "A Thirst for the Authentic: Craft Drinks Producers and the Narration of Authenticity”. Loughborough University. https://hdl.handle.net/2134/36681. 
A thirst for the authentic: craft drinks producers and the narration of authenticity

Thurnell-Read, T. (2019). 'A thirst for the authentic: craft drinks producers and the narration of authenticity', British Journal of Sociology

https://doi.org/10.1111/1468-4446.12634

Dr Thomas Thurnell-Read

School of Social Sciences

Loughborough University

Loughborough

LE11 3TU, UK

Email: t.thurnell-read@lboro.ac.uk 


\title{
A Thirst for the Authentic: Craft Drinks Producers and the Narration of Authenticity
}

\author{
Dr Thomas Thurnell-Read (Loughborough University)
}

\section{Introduction}

While concerns about authenticity have a long history in philosophy and sociology, and it remains 'a resilient concept in consumer society' (Zukin 2008: 745), a unifying factor is that the desire for authenticity is seen as a symptom of dissatisfactions with modernity and modern configurations of social life (Boyle 2003). The longing to identify and possess authenticity, be it in people, places or things, emerges from the 'malaises of modernity' where disenchantment, individualisation and instrumental rationality lead to the 'narrowing and flattening of our lives' (Taylor 1991: 6). Whilst most recent studies of authenticity in consumer culture have focused on consumers and their perceptions of what is or isn't authentic (Beverland and Farrelly, 2010), the aim of this article is to identify how small and independent brewers and distillers make 'authenticity claims' (Ocejo 2017: $69)$ through the narratives they use to add meaning and worth to their products.

The growth of a diversity of cultural 'micro-enterprises' that merge traditional forms of skilled artisanal making with an ability to mediate and perform configurations of 'good taste' is an increasingly prominent feature of post-industrial economies (Scott 2017). Boltanski and Esquerre (2016: 33) have sought to conceptualise the use of narratives to marshal cultural value and to ascribe that value to products and the people involved in making them, 'enriching' them with value and 'a kind of aura surrounding them, signifying that they are exceptional' as being increasingly prominent in Western economies as they continue to shift away from mass production and consumption. By applying this concept of 'the work of enrichment' to a discrete empirical case, and by aligning it with wider long running debates about 'authenticity' and 'craft', the article extends Boltanski and Esquerre's argument to new modes of constructing valuation.

What follows is an analysis of how the narratives of craft drinks producers communicate authenticity claims and, in doing so, create value. I do this by proposing a typology of six 'modes' of authenticity which are deployed in various combination by the research participants as they talk about their products and their work. The analysis of these narratives provides insights into contemporary developments in ideas, and ideals, about work, consumption and material culture and contributes to debates about authenticity, craft and valuation.

\section{Just Like the Real Thing? Authenticity and Modernity}

Rather than occupying its own discrete field of study, the concept of authenticity has arisen across disparate topics of enquiry including art (Trilling 1972), tourism (MacCannell 1976; Wang 1999), politics (Liebes 2001), education (Kreber 2013), heritage (Bold, Larkham and Pickard 2018), marketing (Gilmore and Pine 2007), and media and communication (Duffy 2013). Whilst definitions of this 'troubling concept' (Pettinger 2015: 285) are varied and contested (Wang 1999; Duffy 2013), a unifying concern is the desire to locate the true or 'real' expression of something in the face of trends towards homogenisation, rationalisation and standardisation that have long been seen to characterise modern life (Boorstin 1961; Weber 1978). For Charles Taylor (1991: 5), in his seminal writing on authenticity, the modern enthralment with the authentic represents:

'...a widespread unease that instrumental reason not only has enlarged its scope but also threatened to take over our lives. The fear is that things that ought to be determined by other criteria will be decided in terms of efficiency or "cost-benefit" analysis' 
It is not therefore possible to consider authenticity without exploring the conditions under which the concept, and the enduring fascination it seems to elicit in many Western cultures, emerged and endured. Lindholm (2008), for example, suggests that the concept of authenticity arose historically at a time of rapid social change, where the 'spaces of ambiguity' opened by the breakup of feudalism and the resulting processes of urbanisation led to 'feelings of alienation and meaninglessness, as well as a greater potential for guile and deceit' (Lindholm 2008: 3). It is the apparent proliferation of inauthenticity in the modern world, well charted in the critiques of mass culture and consumer society that dominated the latter part of the $20^{\text {th }}$ century (Benjamin 1968; Adorno 1991; Baudrillard 1998), which bestows authenticity with its meaning and value. Central to these accounts is 'the notion that mass culture is inauthentic culture' (Frosh 2001: 542) and the idea, by implication, that authenticity can and should be sought as an ameliorative of the alienating influences of modernity (MacCannell 1976).

Given that such authenticity claims have been increasingly framed as a means to gain status, recognition and profit (Gilmore and Pine 2007), recent cynicism asserting authenticity to be a 'myth' and a 'con' (Potter, 2010; York, 2014) is largely stirred by the apparent ease with which consumers are 'duped' into accepting as authentic things that have been knowingly fabricated as such. More recently, however, some scholars have sought to step away from a critique which simply condemns the naiveté of those who too easily accept authenticity claims uncritically. Importantly, the likes of Sharon Zukin (2010) have asserted that authenticity is something 'achieved' not 'innate', and that for a deeper understanding of the power of authenticity in the modern world we must look to its production, and contestation, on the ground through the interactions of people, places, things and ideas.

\section{The Work of Crafting Authenticity}

Related to these long-running debates about the emergence of authenticity as a particularly valued quality in modern culture is a related, though more recent, academic concern with craft objects and the labour which produces them. Thus, in spite of - or, more accurately, because of - the standardisation and predictability which characterise contemporary mass production of goods and services (Ritzer 1993), there remains a 'human enchantment with the process of making' (Luckman, 2015: 70). In a parallel and mutually reinforcing development to the yearnings for authenticity identified above, from the mid- $19^{\text {th }}$ century onwards the idea of 'craft' and 'craftsmanship' emerged at as a way of thinking through modernity and its advances when industrialisation was advancing at its most rapacious (Adamson, 2013). From this time onwards, craft has been upheld as offering redemption from what Konings (2015) refers to as the 'dissembedding narrative' that casts capitalism as corrosive and fragmentary, deleterious to human connection beyond the cold logics of the market economy.

The recent resurgence in interest in the idea of craft and craftwork foregrounds these concerns about re-establishing connections and engagements between products, consumers and producers beyond rational market exchange. Thus, handmade objects are said to 'offer a sense of the 'authentic' in an 'inauthentic' world' (Luckman, 2015: 68) and the possibility of reengaging the consumer with the production process from which they have become detached (Ocejo 2017). Craft or 'artisanal' products, therefore, frequently make promises to take the consumer back to a time before the qualities and traditions of the product were diluted by mass production and tainted by the dominance of corporate profit motives over those relating to taste, quality, tradition and sociality (Cope 2014). 
Beyond the craft objects themselves, the labour through which they are crafted with care, skill and passion in particular, has been the focus of much recent work. Most notably, Richard Sennett followed his analysis of the corrosive 'illegibility' of modern work (Sennett, 1999) with a detailed examination of the potential for craftwork to illustrate avenues for understanding and reclaiming the more human qualities of labour lost to instrumental rationalisation. For Sennet - and the likes of Crawford (2009) and Korn (2013), whose essays reasserting the value of making things with your hands have found an increasingly receptive popular audience - thinking about craftwork involves a reappraising of long-held assumptions about the qualities of 'good' and 'bad' work. Such accounts readily draw a contrast with the tradition of sociological concerns that posit modern work as alienating (Marx 1959) and deskilled (Braverman 1974), instead positioning craftwork as not just associated with skill and knowledge but also with a redemptive potential to foster personal control, development and self-actualisation (Korn 2013). Notably, craftwork has allowed renewed interest in the working body, in how skill and expertise becomes embodied (O'Connor 2005) and how 'craft, emotional and aesthetic labour are entwined as dimensions of skilled embodied labour' (Pettinger 2015: 284).

These accounts of craftwork tend to zero in on the maker and their interpretation of the process of making tangible objects noted for their richness and quality. Such objects do not, however, speak for themselves and the authenticity of any craft products must still be narrated or performed and, as such, is open to contestation. Thus, while recent studies by Paxson (2012), Cope (2014), ThurnellRead (2014) and Ocejo (2017) offer empirical evidence of craft or 'artisanal' workers espousing the benefits of their labour as being embodied, skilled and self-expressive, they also emphasise the importance of how craft objects and craftwork are communicated. As Cope suggests, 'narrative is one of the key ingredients in each of the products, for artisans must tell their story and the story of their industry to add value of the products that for so long have been available in cheap, lowerquality, mass-produced varieties' (Cope, 2014: 200). Similarly, the craft workers studied by Ocejo (2017: 12) elevate their products through their interactions with customers and sought to inculcate similar beliefs in them through 'service teaching' where not just the physical qualities of the product but the philosophical and social values underpinning its production could be performed and disseminated. Many craft enterprise workspaces, such as breweries and distilleries, open their doors to inquisitive customers who, through formal tours, through guided tastings on site or more informal interactions, are able to witness craft work taking place in situ as an embodied performance. Narrating a good story about the product being offered is of vital importance meaning that, as Smith Maguire and colleagues (2017: 33) note in their study of craft beer producers, 'these stories are always about more than the beer in the glass'.

What follows is therefore not an account of craftwork itself but an analysis of how craftwork and the making of small batch and high value products involves communicative and performative acts. This article adds to these debates by analysing the narratives by which craftwork is communicated as being authentic. It does so by drawing specifically on Boltanski and Esquerre's (2016) recent conceptualisation of 'the enrichment process' by which value is signified and attached to products, people and places.

\section{Methods and Context}

The analysis is primarily based on two sets of qualitative semi-structured interviews. The first involved 20 workers in various small and independent breweries and took place between July 2011 and August 2013. The second consisted of 20 interviews with independent gin distillery workers and was conducted between July 2017 and February 2018. In both cases, the recruitment strategy involved the researcher identifying businesses through their websites and social media presence 
and, after verifying that they were indeed small and independently owned, making contact via email. That response rates were high (nearly $50 \%$ of distilleries contacted agreed to participate) is some indication of the readiness with which such businesses tell their stories and seek to communicate about their products and their work. In all cases, interviewees were provided with Participant Information Sheets and signed Informed Consent documents indicating their willingness to participate. Pseudonyms were used for individual interviewees and content relating to the business and its operations, for instance the names of specific products, have been presented in such as a way as to not reveal the identity of the participants.

A core of distillery and brewery participants were based in the East and West Midlands respectively due to their geographical proximity to the researcher, with further participants located in London and Southeast England, Cornwall and Devon in Southwest England and cities in Northern England such as Newcastle and Manchester. Importantly, given the notable propensity of journalistic accounts to treat the recent craft drinks sector 'renaissance' as an uniquely urban phenomenon centred on specific 'hipster' neighbourhoods of East London (e.g. Bawden 2015), this geographical distribution ensured that urban, rural and suburban areas beyond the London metropole were represented. Social class and age was notably varied, yet only five of the distillery interviewees, and only one of the brewery interviewees, were female.

In addition to interviews, observing places of production and sites of consumption, such as festivals, bars and pubs, as well as 'meet the brewer' nights, tutored tastings and media appearances added a further layer to the analysis. While the research primarily focuses on interviews, it was possible to follow the narratives solicited during interviews across communicative forms such as the 'Our Story' and 'Meet the Team' pages of brewery and distillery websites. It is also worth noting that interviewees also indicated that they frequently had similar interactions with others such as local journalists asking them how and why they started the distillery or brewery, and enthusiastic customers attending distillery tours or meet the brewer events to ask questions about their working day, the pleasures and frustrations of their work. This meant that in many instances, the initial stages of interviews were characterised by some quite well rehearsed 'stock' answers and it was only with further elaboration and prompting (Gillham 2005; Roulston 2010) that more nuanced and candid narrative forms emerged.

\section{Craft Drinks Makers and Authenticity Narratives}

Stories are vital in bestowing value on craft or artisanal products and justifying a sale price typically much higher than mass produced national or international versions of the same class of product (Cope 2014; Ocejo 2017; Smith Maguire et al, 2017). The construction and communication of narratives were seen across interviews as well as featuring prominently on company websites. For example, the website text of one London craft gin distillery notes that their 'story began' when the owner 'moved to London from Australia' and 'discovered what would become his true passion'. Once he became 'fully immersed in investigating the distillation process', and after a 'couple of experimental years', his efforts were rewarded when 'he perfected the recipe' and his artisan gin 'was born'. This story of 'One man's journey to create the perfect gin' represents a well-worn quest narrative where a hero is called into action to undertake a search from which he will return with riches ('the perfect gin') and heroic status (he becomes 'affectionately known as 'Moonshine Mark' by the regulars at the bar').

So too during interviews did it become clear that the stories told about the production of beer and gin were of central importance to the businesses, allowing them to harness 'the power of narrative' (Cope 2014: 116) to add value to their products. Danny, for example, explained that 'people are 
really desperately wanting to hear the story and how it happened' and recalled how even from the initial months of the distillery going into operation he could spend each and every weekend at events and festivals where he'd talk 'all day long' about the distillery. To deconstruct these authenticity claims further, the following sections presents a typology of six modes of authenticity. All of the 40 interviewees draw on several of these modes in combination, with each using modes in particular combinations to formulate their own authenticity claims which 'enrich', and therefore add value to, their products.

\section{Procedural Authenticity}

One of the most common assertions made by participants during interviews related to the procedures by which their products were made. This involved demonstrating detailed knowledge of the process of brewing or distillation and in many cases meant that, where interviews were conducted on site, I was invariably offered a tour of the brewery or distillery to view equipment, stores of ingredients, and products in various stages of readiness for sale before sitting down to carry out the interview. Such tours were accompanied by evidently well practiced commentaries about processes and on more than one occasion references were made to this being where the magic happens'.

More specifically, narrating processes allowed interviewees to foreground the skill and control evident in their work that they felt set them apart from others. Thus, for Felix, being in complete control of the production process meant that 'it is very much important that most of that is done by us, we don't farm out bottling or labelling'. This was seen to add value to their product and enabled them to draw a ready contrast to 'some people' who 'make gin in their geographical area and then send it $\mathbf{3 0 0}$ miles down the road to be bottled'. Meanwhile, Michael discussed how his 'ability to understand the more technical elements of brewing' meant they could stand out from other lessskilled brewers to 'produce more flavoursome beers than average and the quality of our beers is better than average'.

For many, the visibility of the processes by which their product was made was significant. Distillery founder Darren explained how 'the intention was to have a site that is a real site' at which, in contrast to some distilleries where 'it's all beautifully manicured and then you exit via the gift shop', visitors would 'turn up and some days it's complete pandemonium, there's hoses everywhere and there's bottles everywhere there's staff and there's all sorts of things going on'. For Darren, the very visibility of the distillation process and the labour involved meant that 'part of the brand messaging is that it's completely authentic [and] nothing leaves the site unless it's in a bottle'.

In such cases, where the 'transparency of process' appears highly valued by producers (Ocejo 2017: 71), having 'nothing to hide' allows authenticity to be 'displayed' through a lack of Goffman-esque backstage region distinguished by its 'open characteristic' which intentionally allow outsiders a glimpse of the inner workings (MacCannell 1976). Many, but not all, breweries and distilleries were in some sense 'open' to the public. This ranged from regular organised tours and tasting events, which in some cases significantly supplemented the income from the sale of beer or gin, to nominally private workspaces where the brewer or distiller still showed a willingness for local customers and other interested individuals to feel able to 'pop in and say hello'. For example, during a tour of a distillery in Southeast England one distiller described the distillery as 'such a lovely, fun place to be' and a place where they would regularly invite groups of key clients 'to come out from London and just hang out, to get to know us and see what we are doing here'. 


\section{Material Authenticity}

Related to accounts of processes of fermentation and distillation was the specific and very common focus on the materials involved in production and, of course, the product itself. Throughout interviews, and across websites marketing materials and observed interactions at tours and tasting events, naming specific ingredients was an overt means to foreground issues of quality and value. For brewers, this involved vocally expressing the choice to use higher quality malts, such as marris otter, and particular hops often associated with celebrated hop growing regions, such as Fuggles from Kent or Willamette from Oregon. For distillers, a focus on the botanicals used to impart flavour in the distilled spirit were key and distillers could speak at length and in detail about how precise combinations of botanicals were tested and honed for particular flavour profiles. Indeed, during one interview, the participant gestured to crates of citrus fruit awaiting peeling by hand for the next distillation run by saying 'that lot awaits me once we're done here [with the interview]'.

Specifically, the way in which the choice of ingredients were selected set a particular tone. Frank spoke of how 'it's never been cheap, if you're going to buy Marris Otter malt you're going to pay a premium' and how he'd tried cheaper alternative malts that where 'not bad, because I wouldn't brew it if it was bad but my god can't you taste the difference'. Likewise, Felix was able to emphasise how it was important that his partner 'hand forages dandelion and burdock' because it meant that their ingredients for their gin were found 'in the heart of the city'. Similarly, distillery founder and owner Stanley spoke of how:

'Our warehouse is the outside so my role is to make sure that the juniper berries are brought in at the right time and are ready and Douglas fir and blackcurrant leafs are already so I have a provider role...I've always wanted to do something that is all the very very highest quality, and suffer the consequences in terms of volume and profit'

The purpose of close discussion of ingredients seems to be two fold. First, it is possible to differentiate the product as being made of good quality ingredients which possess superior qualities in terms of the tastes, textures or aromas that they contribute to the final product. Second, and perhaps as importantly, discussing materials allows a story to be told about the ethos of the makers, who narrate their ability to skilfully identify ingredients to use and to gauge their impact on the quality of the final product. Importantly, both Frank and Stanley posit themselves as discerning and uncompromising by being unwilling to select cheaper yet inferior ingredients.

The procedural and material modes of authenticity were particularly evident in the various events where brewers and distillers would interact with customers at brewery tours, tasting events and food and drinks festivals. On such occasions, observed during the research process, heads of hops, grains of malted barley or juniper berries would be produced from sacks or jars for customers to pressed, squeezed, tasted or smelled by visitors. Narratives about the processes and ingredients would be elaborately physically through demonstrations of equipment or, often, through ritualistic presentation of samples of drink to be tasted and appraised.

\section{Geographical Authenticity}

Across both sets of interviews, and as discussed elsewhere in relation to craft distillers (Cope 2014; Ocejo 2017) and brewers (Schnell and Reese 2014; Thurnell-Read 2015), locality and place are important components of many producers' narratives. Spracklen (2011: 109), for instance, deconstructs the manner in which Scottish whisky branding is 'couched in the myths and traditions of Scotland', whilst craft brewers have been said to invoke local symbolism in 'the wilful cultivation of a sense of rootedness and a sense of place' (Schnell and Reese 2014: 185). 
Numerous participants had drawn on local geography and place symbolism in the branding of their products and a number of participants spoke about being 'the first' distillery or brewery a particular city, town or region. Some drew on the value already associated with a particular place by cultivating an association with the Areas of Outstanding Natural Beauty, Special Conservation Area, or national parks they were located within or near. Being located in remote seaside location in the country of Cornwall allowed Yasmin to position her gin in a unique way:

'Cornwall is a brand and a lot of work has been done so wherever you go people know Cornwall and it's just got that lovely image of freshness and this rural side and freedom and clean air and it's got all those things. So when you say it's from Cornwall, automatically all these things come into their head so you know that they're going to like it'

For Yasmin, and others, once established such connections could be reinforced with the use of social media to depict products against backdrops of nature such as Cornish coastlines or Northumbrian moorland whilst others timed their posts to align with local events and even made use of local dialect words or slang.

Analysing these instances of geographical authenticity reveal the importance of loyalty and trust as being associated with geographical proximity. Jonathan, for example, asserted locality as being vital in the production and maintenance of the quality of the product by saying:

'Obviously if we can build up local customers it builds up the brand we've got and builds up a base of customer loyalty in the area, it cuts down our transport costs and cuts down on our time and means we're able to keep a lot better control on quality and have, you know, a lot better relationships with publicans and be able to support them in a way that if the beer is going off half way around the country you can't, you've got no idea.'

Further still, being made in a particular locality was often cast in contrast to the apparent placelessness of many mass produced brands, with brewer Gus describing his beer as 'made by a local boy' and distiller Eddie saying his gin gets 'lots of interest in the local area, the local media'. For many, being associated with a specific town, city or rural area was a central means to distinguish their product form national and international brands.

\section{Temporal Authenticity}

Whilst the first three modes of authenticity outlined are all visible, in that process, materials and places can all be seen or, at least, represented with relative ease, the next type of authenticity claim evident in interviewees' narratives is less visible. Many made reference to either tradition, in a general sense, or time in a more specific way by stating particular time periods. Archie, for example, made use of a specific temporal reference point in saying 'so why do we make gin the way we make it? Well it's because that's how it would have been made in this pub in 1840, you know'. The wider framing of this was that his traditional method of distillation, being slow and at times laborious, was at odds with modern demands of what he described as 'an internet generation, a wireless generation' who 'want a 25 year malt Scotch but they only want to wait 10 years for it'. Likewise, brewers Gus and Phillip and distiller Terry acknowledged 'a certain appeal in doing things [in] a way you know a brewer would have done it hundreds of years ago', 'a timeless quality' and 'a joy in taking things back to the basic traditional process' respectively. Such themes featured prominently in many websites where references to the use of a 'traditional slow distillation method' or beer being brewer 'in time honour tradition' were common.

Many interviewees drew on references to history and tradition by, for example, utilising local traditions and myths in the naming of products (see Thurnell-Read, 2015) in a manner which clearly 
resonates with Boltanski and Esquerre's (2016) discussion of how harnessing heritage allows luxury brands to associate with the values attached to particular time periods and historical figures.

However, not all interviewees were backwards looking. Some located themselves very much in the present and gave detailed accounts of the importance of the 'fresh, contemporary vibe' they were looking to exhibit. Due to her age, being only a teenager when setting up her distillery, Rowena made reference to needing to find a distinctly contemporary style for her gin and its branding that would fit with her own age and identity as well as to curtail some pre-empted criticisms that sought to infantilise her and her product by implying that someone so young would make 'kind of like raspberry bubble gum gin'. Similarly, Alex acknowledge that the 'retro' appeal of real ale could be positioned as 'coming back to our roots and tradition and history which is great' but then insisted that his long-term plans involved 'positioning the brand slightly away from' an association with traditional imagery and events such as rugby matches and instead towards 'contemporary cool events, the boutique events'.

\section{Oppositional Authenticity}

Perhaps the most commonly used mode of authenticity, and one already evident in many of the examples offered above, was to contrast the way others were inauthentic in order to enhance one's own position of authenticity. Examples of this included both general references to 'mainstream' brands and 'mass produced' products and more specific invocations of particular brands from which an oppositional contrast could be drawn. As an example of the former, in stating that 'real ale is difficult if you're a multinational company, it's a living product they can't necessarily give it the care and the time it needs', Michael could position his own small-scale efforts as being couched in a language of attention and 'care' both overlooked and undervalued by larger corporate producers. A common theme in both sets of interviews was that there was both an opportunity and a necessity for craft producers to 'get out there' and be seen by customers in a way that the dominant brands could not manage. Distiller Austin, for example, spoke of being 'always out and about, chatting to all sorts of folk' and explained that it gave him and his products 'personality and that visibility that you just don't get with a brand like Bombay Sapphire'.

Many interviewees used the perceived practices or values of multinational corporations such as brewers Molson Coors and Heineken and, in particular, globally dominant spirits maker Diageo as a foil with which to contrast their own products and processes. For Tina, this involved contrasting the more personalised craft gin distillery where 'you've got the person who made it standing there' with the anonymity of larger brands where 'there's no face attached to Beefeater or Bombay Sapphire'. For others, this involved quite strong statements that their work was not (solely) motivated by profits and that the monetary rewards of making 'good' beer or gin were only secondary to other concerns. In this regard, the timing of the interviews meant that the 2011 buyout of Cornish brewery Sharp's by Molson Coors for $£ 20 \mathrm{~m}$ and the 2016 purchase of craft gin industry trendsetter Sipsmith by Japanese giant Beam Suntory for a figure reported as being in excess of $£ 50 \mathrm{~m}$ were, at the time of the respective data collection periods, recent events providing a ready referent for interviewees to frame their own business ethos in contrast to. Notably, then, there was ambivalence, if not overt animosity, to the idea that the authenticity narratives used by small, independent, producers which, of course, both Sharp's and Sipsmith were themselves until relatively recently - could be 'scaled up' and used by organisational entities with a more pronounced corporate structure and a national or international market share. Indeed, in recent year various international corporations that have bought craft drinks enterprises in multimillion pound deals have had to undertake extensive public relations exercises when sections of the customer base abandon them on the grounds that 
corporate ownership undermines the values that many see as crucial to the craft ethos (e.g. Wood, 2017).

One interesting upshot of this is that as some of these small-scale businesses succeed and look to expand they must negotiate their own increasingly corporate operations with their earlier construction of themselves as oppositional to 'big businesses'. Negotiation of expansion therefore presents some difficulties in maintaining certain narratives, particularly those that emphasise certain values as being above corporate measures of success such as turnover, market share and profit. A strategy of emphasising organic growth, where the implication is that the core values of the business have not been lost to profit motives of the owners or, worse, of outside investors, was employed by several participants. Michael, for instance, spoke of the steady growth of the brewery he founded and ran with his wife as having expanded 'nicely' because 'we've not injected huge sums of money into it, as other people have. We've just let it grow organically each year, year by year'. Similarly, Scott's brewery move from a small unit in East London to a larger unit in North London was depicted in the 'Our Story' text of their website as a result of how the business had 'steadily grown' yet, as the narrative was also careful to indicate, would remain 'an independent business and employ a small team of people'.

Beyond this frequently invoked 'David and Goliath' narrative - where, as Stanley explained, they could 'dream in a way that Diageo doesn't dream' - many interviewees spoke at length about, and saved particular disdain for, those who invoked the language and imagery of craft without actually being involved directly in making their own gin or beer. For example, Archie spoke with open hostility by saying:

'It's all made somewhere else now anyway, so it's bollocks, and well it's like this craft gin revolution, we know for a fact that 50 of the premium craft gins are made by the same place and... it's made in Langley's in Birmingham or wherever and they've got a recipe sheet there for [prominent brand] and they crank that out. Fifty thousand bottles of that and then I'll crank someone else's out'

Here, Archie pours scorn on those who pass off gins 'cranked out' through industrial scale production as craft products. Such attempts to pass off a gin or beer made by someone else were evidently perceived as deceptive and insincere, and as involving a cynical attempt to profit from the value created by others without having 'earned it the hard way' through protracted and often painstaking process of acquiring skill and competency. Terry, in particular, was vocal in his concern that such 'cheque book distillers', who 'casually write out a cheque' to have their gin 'churned out' by someone else, were 'one of the biggest threats to everything a lot of us have been working hard towards' undermining their own efforts to 'do things the right way' and by engendering mistrust in a customer base already becoming wary of terms like 'craft, artisan and hand-made or local being flogged to death through overuse'. Such statements indicated that in a sector that has come to place a great and increasingly nuanced emphasis on authenticity, the biggest sin is falsity.

\section{Biographical Authenticity}

The five modes of authenticity described so far are all closely aligned to the product and how and where it is made. The final mode to be presented here differs from this in being more about the person making the product than the gin or beer itself. Yet, specifically, the two are linked in a number of significant ways. The product was often spoken of as being an expression of the maker's own taste and character. Daniel, for instance, explained that 'I thought l'd like to do something like that, not a copy but my own version...you want to brew beers that you like yourself of course, if I didn't like it I wouldn't want to brew it' while Felix justified a 'Navy Strength' gin as 'a product for 
me' produced for his own personal satisfaction as much as for commercial reasons. Notably, concurring with existing studies on craft and self-fulfilment (e.g. Thurnell-Read 2014; Luckman 2015) where the craft producer 'invests' their own sense of selfhood into the object produced (Campbell 2005), many participants spoke of the drink produced eliciting strong feelings of pride and selfworth. For example, Jacqueline, the co-owner of a family run distillery in Southwest England, recalled how 'we went into a bar in Dublin, and there was [our gin] and it was like...you know, it's just that kind of that... "Yeah!" [exhales]. Huge amount of satisfaction in that'.

As I have explored elsewhere in relation to the brewery interviews (Thurnell-Read 2014), the work of making craft drinks is 'integrated into a wider biographical account' that includes not just career changes but life course transitions, becoming a parent, going through a divorce or moving to a new town or city. Thus, earlier work in other occupations was often cast as incongruous and in contrast to brewing or distilling. Eddie, for example, explained that:

"I knew I could do something more interesting and better sort of things. So being, sort of, what I would consider a "creative" person, and... I mean, I've seen what we're doing here as the culmination of a lifetime of experience. Sort of, 10 or 15 years to manifest itself into what we're doing now, sort of thing. I wanted to do something creative, and I wanted to do something that would give me a better lifestyle, and I wanted to do something that people enjoyed'

Such narratives align well with Korn's (2013) account of the 'holistic quality of craft' which brings together materials and ideas with the person through complex biographical reflections of personal growth, development and self-realisation. Notably, others spoke of their work as revealing something about themselves they'd hitherto not well understood. For example, Steve spoke of his previous enterprise buying and refurbishing rundown houses to sell on or rent as having 'no structure'. Going on to discuss the long and busy days at the brewery, and the methodical routine imposed by the various stages of the brewing process, he recalled how he had come to realise that the previous situation where he 'just did stuff what I wanted to basically', in hindsight, 'doesn't work very well for me'.

Such narratives of self-discovery and self-expression evidently found a receptive audience. Indeed, various studies show that many consumers exhibit this strong desire to know more about the relationship between the product and its maker (Cope 2014; Ocejo 2017) while, further still, work in the culture sector more generally has been shown to involve self-assertion and the successful declarations of who one is in terms of personal tastes, passions and values (Dubois 2015). Here, the mode of biographical authenticity involves narrating how 'truth-to-oneself', as part of 'a project of ontological fidelity' (Frosh 2001: 542), can be put to use in the successful marketing of the product and its maker as desirable and of value.

\section{Discussion}

The above findings illustrate the presence of six modes of authenticity in the narratives constructed by craft distillers and brewers as they talk about their products. It has sought to demonstrate how these modes of authenticity, in combination with each other, become animated through communication of stories about craft drinks, their makers and the places in which they are made. The data explored above show how the contemporary thirst for authenticity urges people to 'tell stories' as 'people want to hear about real people living real lives in real places' (Boyle 2003: 274). Further, it provides evidence of the increasingly common need for businesses to be involved in 
cultivating 'collective fables' through stories about the company, their brands and their products (Salmon 2010: 11).

On one level, this might all simply be seen as astute marketing strategies by which a small-scale producer can position themselves in relation to a market dominated by an oligarchy of major corporations and increasingly saturated with competitors of small and medium sizes. On another level, however, the priority placed on establishing authenticity is of specific sociological interest for the way in which it reveals concerns about contemporary figurations of work and consumption and, in so doing, illuminate the importance of human interactions with non-human materials, processes and commodities. Thus, following Potter (2010: 13), we might see authenticity as 'a way of talking about things in the world, a way of making judgements, staking claims, and expressing preferences about our relationships to one another, to the world, and to things'. In being a primary means by which the 'commodification of authenticity' (Lindholm 2008) can be achieved, the ability to devise and successfully deliver such narratives is uniquely valuable to those involved in the small-scale production of high value products. Whilst there is a long history of large businesses co-opting the language of rebellion (e.g. Frank 1999; McGuigan 2009) and many large scale beverage producers also engage in branding exercises drawing on motifs of authenticity (Spracklen, 2011), participants in this research all felt that the viability of their businesses rested in their ability to differentiate themselves and their products from mass produced alternatives through nuanced narratives and performances of authenticity.

This resonates with Boltanski and Esquerre's (2016: 35) recent analysis of a shift towards economies that prioritise the process by which commodities are enriched 'through the use of a narrative device that highlights certain of the object's qualities, thereby producing and formatting differences and identities, which are the primary resources of enriched economies'. Products are still made in a physical sense (indeed, here it is one of the crucial components of several of the identified modes of authenticity) but much of 'the work of enrichment' (Boltanski and Esquerre 2016) is achieved through the marshalling of symbolic meanings, cultural value and affective attachments. When many participants spoke during interviews of needing to be able to effectively communicate their ethos to consumers and to convey their 'story' not just through branding but through the performance of their labour, for instance by embodying their skill and passion at 'meet the brewer' events or during distillery tours, they invoke a particular conception of the labour of creating value in a 'culture of authenticity' (Taylor 1991). The craft producer-self must be passionate, knowledgeable, physically and emotionally immersed in their labours and physically and emotionally open to be viewed and evaluated by others. At brewery tours and meet the brewer nights and during gin tasting events and food and drink festivals, the craft ethos must be performed verbally and bodily. Extending Boltanski and Esquerre's (2016: 33) observation that enrichment is not just of the object but of 'the spheres in which they are designed and circulated: to the human beings surrounding them', the work of enrichment is not just a useful marketing strategy nor solely a one-way process in which the narrators add value to the product only. Rather, the symbolic meanings being created and deployed are lived and embodied by the producers and in various ways shared by their customers as they buy into and become co-producers of such narratives.

In addition, the analysis has illustrated why authenticity is 'notoriously difficult to define' ( $O$ 'Neill, Houtman and Aupers 2014: 587). Indeed, it is its multifaceted, performative and times contested nature that have led others to note its 'schizoid quality' (Zukin 2010: xii) that means it must be treated as a 'moving target' (Boyle 2003: 39). Authenticity does not exist in any fixed objective form. Rather it is worked upon through the narratives and performances that can, for a time, successfully draw on a combination of modes of authenticity in order to tether different meanings and values 
together in a way that appears congruent with prevailing values, ideals and desires. The participants of this research might be thought of as working at not just the making of gin or beer, but labouring in the construction and communication of meaning as part of the 'enrichment process' identified by Boltanski and Esquerre (2016).

It is apparent that the labours of those involved in creating such value are readily co-opted by corporations which represent the structural forces that such authenticity is propositioned as opposing (Belasco 1993; Frank 1999; McGuigan 2009). Words like 'craft' and 'artisan' are not easily regulated and can be easily adopted by large corporations looking to attach a sense of quality, tradition and passion to their products (Cope, 2014: 2). Whilst many interviewees expressed faith in the knowing cynicism of a community of committed and knowledgeable consumers to spot corporate attempts to fabricate 'craft' products, others spoke with concern, and some with notable anger, of the ease with which authenticity narratives, as the product of their labour, could be appropriated by others. Interviewees were highly aware of the threat of big corporations co-opting the language and symbolism of craft and authenticity, but most felt a measured optimism that their customers could tell the differences between genuine small and independent producers and international corporation's affectations of craft discourses.

Interestingly, a number of interviewees appeared to be seeking to mitigate any criticisms they themselves might receive for succeeding in their efforts to construct and 'sell' authenticity for profit by using some intriguing counter-strategies. One common approach involved self-deprecation, with distillers like Owen highlighting their amateurish beginnings where he 'started very, very small scale in my brother's garage' and 'really had no clear idea, whether we were good enough, or if we would be taken seriously'. So too others, such as Paul and Noah respectively, reverted to underplaying their work as just 'a bloke and his missus making gin' who simply 'put it in a nice bottle and it tastes good' and by saying 'We don't do that. We don't do superfluous bullshit, we do gin and we do whisky'. Others used ironic distancing. For instance, Geoff recounted how their beer bottles had featured 'facts' about local landmarks and events that were 'so obviously wildly made as to single a willingness to playfully subvert more staid attempts to brand products through association with local history and culture. Such strategies again highlight the importance of understanding authenticity as being both discursive and performative in their constitution.

\section{Conclusions}

By exploring the case of how small-scale independent brewers and distillers talk about their products and the processes, this article has identified six modes of authenticity and demonstrated how combinations of these modes are central to the construction of commercial and cultural value. It has sought to illustrate how authenticity, rather than being something with an objective existence that can be defined and isolated, is created and defended through communicative and performative acts of which the storytelling practices evidenced in data derived from interviews, as well as websites and articulated during distillery and brewery tours, are a telling example. Brewers and distillers went to great lengths to ensure a clear and consistent message was communicating across these sites. Thus, authenticity is a discursive construct (Frosh 2001), and only through its telling does it become animated and only once expressed can it be claimed and, if needed, defended. In contrast to modern work and mass consumption, both seen as alienated and rationalised and as such lacking in meaning or worth, narratives of authenticity allow these individuals to position their labour and its outputs as meaningful in a holistic sense and operative beyond not solely in relation to the 'cold' logic of market capitalism. 
At least part of the appeal of such products, therefore, does not reside in their objective qualities such as how they taste. Rather, the product becomes the nexus through which understandings about the relationships between people, places and things can be made visible. These narratives allow those narrating them to (re)establish connection between products and their maker and to situate the act of making in space and time. Further, such narratives draw readily on discourses of self-discovery and self-hood which are widely popular across popular culture (e.g. Duffy 2013). In this sense, a common theme was often that these small and independent producers were either returning to or creating new ways of doing business in more socially embedded ways. The appeal of handmade, small-batch, commodities is that they can exhibit quality and uniqueness in a way that mass production fails to (Cope 2014) and therefore such products represent the potential ability for craft discourses to be 'resignified' as something radical and oppositional (Luckman 2015).

Such stories are of their time in that particular narratives need both people willing to tell them and those willing to hear them to receive and maintain cultural visibility. That there is an evident desire to hear such authenticity narratives therefore illuminates wider concerns with the dissatisfactions of modern work, consumption and social life that have far reaching roots in sociological thinking. Tellingly, such businesses and the narratives that they disseminate have flourished during a period of extended economic instability and, if we follow Boltanski and Esquerre (2016), are becoming a core site for the creation of both economic and cultural value through processes of 'enrichment'.

The contribution of this article has therefore been not just to add to debates about the nature of authenticity and craft in contemporary culture. It has also sought to extend Boltanski and Esquerre's argument through empirical insights. Whilst concepts such as craft and authenticity appear, on first inspection, as being firmly rooted in the past, I draw on Boltanski and Esquerre (2016) as a means to show not just their contemporary relevance but their ongoing, and likely increasing, importance to emergent practices in the configuration of value in the wider economy.

Further research might explore how ideas of craft and authenticity diffuse through popular culture over time and might seek to better understand the role of intermediaries such bar and pub owners, drinks writers and trade organisations in sustaining, developing or contesting the narratives of producers (See Thurnell-Read 2016). Likewise, ongoing research will need to trace the wider biographical trajectories of workers in this and other craft related occupations to better understand how socioeconomic background, education and training, and other sites of relative privilege or disadvantage influence the outcomes such activities as setting up a craft brewery or distillery.

The recent exponential growth of this sector may, for instance, have protected many producers from some of the vagaries of the market thereby allowing them to uphold principles over profits in a way that may not be sustainable if the market saturation and subsequent contraction, that many of the interviewees themselves predict, takes place. With ongoing efforts by the largest international corporations to either purchase or create their own 'craft' brands, further research will need to explore and understand the tensions that arise as moves are made to co-opt the modes of authenticity tried and tested by small and independent producers. Future research will need to widen the sampling frame used here in order to capture the use of authenticity narratives across a greater diversity of scales of production. Lastly, the nature of the research methods and context mean that international and intercultural comparisons of craft labour were not possible. There is certainly scope to understand how modes of authenticity and enrichment processes are shaped and reshaped as they move across national borders and into contexts more or less marked by the longterm processes that are said to have given rise to such desires to produce and consumer authenticity (Taylor 1991). 


\section{Bibliography}

Adamson, G. 2013 The Invention of Craft. London: Bloomsbury.

Adorno, T. 1991 The Culture Industry: Selected essays on mass culture. London: Routledge.

Baudrillard, J. 1998 The Consumer Society: Myths and structures, London: Sage.

Bawden, T. 2015 'Cheers! Britain gets a real thirst for 'hipster' beers', The Independent, 22 February 2015: https://www.independent.co.uk/life-style/food-and-drink/news/cheers-britain-gets-a-realthirst-for-hipster-beers-10062936.html.

Belasco, W.J. 1993 Appetite for Change: How the Counterculture Took on the Food Industry, New York: Cornell University Press.

Benjamin, W. 1968 Illuminations: Essays and Reflections. Ed. Hannah Arendt. Trans. Harry Zohn. New York: Schocken Books.

Beverland, M. B., \& Farrelly, F. J. 2009 'The quest for authenticity in consumption: Consumers' purposive choice of authentic cues to shape experienced outcomes', Journal of Consumer Research, 36(5), 838-856.

Bold, J., Larkham, P., \& Pickard, R. (Eds.). 2018 Authentic Reconstruction: Authenticity, Architecture and the Built Heritage, London: Bloomsbury.

Boltanski, L., \& Esquerre, A. 2016 'The economic Life of Things: Commodities, collectibles, assets', New Left Review, 98:31-54.

Boorstin, D. 1961 The Image: Or what happened to the American dream?, London: Weidenfeld \& Nicolson.

Boyle, D. 2003 Authenticity Brands, Fakes, Spin and the Lust for Real Life, London: Flamingo.

Braverman, H. 1998 Labor and monopoly capital: The degradation of work in the twentieth century, New York: New York University Press.

Campbell, C. 2005 'The Craft Consumer: Culture, craft and consumption in a postmodern society, Journal of Consumer Culture, 5(1), 23-42.

Cope, S. 2014 Small Batch: Pickles, Cheese, Chocolate, Spirits, and the Return of Artisanal Foods. Lanham: Rowman \& Littlefield.

Dubois, V. 2015 Culture as a Vocation: Sociology of Career Choices in Cultural Management, Abingdon: Routledge.

Duffy, B. E. 2013 'Manufacturing Authenticity: The Rhetoric of "Real" in Women's Magazines', The Communication Review, 16(3): 132-154.

Frank, T. 1997 The Conquest of Cool: Business culture, counterculture, and the rise of hip consumerism, Chicago: University of Chicago Press.

Frosh, P. 2001 'To thine own self be true: The discourse of authenticity in mass cultural production, The Communication Review, 4:4, 541-557.

George, R. 1993 The Mcdonaldization of Society, London: SAGE. 
Gillham, B. 2005 Research Interviewing: The range of techniques: A practical guide. Maidenhead: Open University Press.

Gilmore, J. H., \& Pine, B. J. 2007 Authenticity: What consumers really want, Brighton, MA: Harvard Business Press.

Konings, M. 2015 The Emotional Logic of Capitalism: What progressives have missed, Stanford, Cali.: Stanford University Press.

Korn, P. 2013 Why We Make Things and Why it Matters: The education of a craftsman, Boston: Godine.

Kreber, C. 2013 Authenticity in and through teaching in higher education: The transformative potential of the scholarship of teaching, Abingdon: Routledge.

Liebes, T. 2001 "Look me straight in the eye" the political discourse of authenticity, spontaneity, and sincerity', The Communication Review, 4(4), 499-510.

Lindholm, C. 2008 Culture and Authenticity, Oxford: Wiley-Blackwell.

Luckman, S. 2015 Craft and the Creative Economy. London: Palgrave Macmillan.

MacCannell, D. 1976 The Tourist: A new theory of the leisure class, London: Macmillan.

Smith Maguire, J., Bain, J., Davies, A. and Touri, M. 2017 'Storytelling and Market Formation: An Exploration of Microbrewers in the UK', in ed. Untapped: Exploring the Cultural Dimensions of the Craft Beer Revolution, Chapman, N., Lellock, J. and Lippard, C. (Eds), Morgantown: West Virginia University Press.

Marx, K. 1959 Economic and Philosophical Manuscripts of 1844. Moscow: Progress Publishers.

Ocejo, R. E. 2017 Masters of Craft: Old jobs in the new urban economy. Princeton: Princeton University Press.

O'Connor, E. 2005 'Embodied knowledge: The experience of meaning and the struggle towards proficiency in glassblowing'. Ethnography, 6(2): 183-204.

O'Neill, C., Houtman, D. and Aupers, S., 2014. 'Advertising real beer: Authenticity claims beyond truth and falsity', European Journal of Cultural Studies, 17(5), pp.585-601.

Paxson, H. 2012. The Life of Cheese: Crafting food and value in America. Berkley: University of California Press.

Pettinger, L. 2015 'Embodied labour in music work', The British Journal of Sociology, 66(2): 282-300.

Potter, A. 2010 The Authenticity Hoax: Why the 'Real' Things We Week Don't Make Us Happy, New York: Harper Collins.

Ritzer, G. 1993 The McDonaldization of Society: An investigation into the changing character of contemporary social life, Thousand Oaks, CA; London: Pine Forge.

Roulston, K. 2010 'Considering quality in qualitative interviewing', Qualitative Research, 10(2): 199228.

Salmon, C. 2010 Storytelling: Bewitching the Modern Mind, London: Verso. 
Scott, M. 2017 'Hipster Capitalism' in the Age of Austerity? Polanyi meets Bourdieu's new petite bourgeoisie, Cultural Sociology, 11(1), 60-76.

Sennet, R. 1999 The Corrosion of Character: The personal consequences of work in the new capitalism, New York: W.W. Norton.

Sennet, R. 2008 The Craftsman, London: Allen Lane.

Spracklen, K. 2011 'Dreaming of drams: Authenticity in Scottish whisky tourism as an expression of unresolved Habermasian rationalities', Leisure Studies, 30(1): 99-116.

Taylor, C. 1991 The Ethics of Authenticity, Cambridge: Harvard University Press.

Thurnell-Read, T. 2014 'Craft, tangibility and affect at work in the microbrewery', Emotion, Space and Society $13,46-54$.

Thurnell-Read, T. 2015 'Beer and belonging: Real Ale consumption, place and identity', In T. Thurnell-Read (ed), Drinking Dilemmas: Space, Culture and Identity, London: Routledge.

Thurnell-Read, T. 2016. 'The embourgeoisement of beer: Changing practices of 'Real Ale' consumption', Journal of Consumer Culture, 1469540516684189.

Trilling, L. 1972 Sincerity and Authenticity. Cambridge: Harvard University Press.

Wang, N. 1999 'Rethinking authenticity in tourism experience?', Annals of Tourism Research 26: 349-370.

Weber, M. 1978 Economy and Society: An outline of interpretive sociology. Berkley: University of California Press.

Wood, z. 2017. 'Camden Town Brewery founder insists big can also be beautiful', The Guardian, $8^{\text {th }}$ July 2017: https://www.theguardian.com/business/2017/jul/08/big-also-beautiful-insists-foundercamden-town-brewery-jasper-cuppaidge

York, P. 2014 Authenticity is a Con, London: Biteback.

Zukin, S. 2008 'Consuming Authenticity', Cultural Studies, 22(5): 724-748.

Zukin, S. 2010 Naked city: The Death and Life of Authentic Urban Places. Oxford: Oxford University Press.

\section{Acknowledgment}

I would like to express my thanks to Dave Elder-Vass and Felix Röesch, as well as the anonymous reviewers, for their helpful comments on earlier versions of this article. 
